\title{
Jurist-Diction
}

Volume 2 No. 5, September 2019

Histori artikel: Submit 1 Agustus 2019; Diterima 8 Agustus 2019; Diterbitkan online 1 September 2019.

\section{PenerapanUndang-Undang No. 44 Tahun 2008 tentang Pornografi terhadap Penangkapan Pelaku Hubungan Sejenis (Gay)}

\author{
Tatag Eko Fitrianto \\ ricardotatag@gmail.com \\ Universitas Airlangga
}

\begin{abstract}
Such relationships have long existed in Indonesia, but lately this year there have been various kinds of polemics. Pros and cons of accompanying and flavoring in cases that increasingly make this case excited and viral in the community. This arises from the turmoil of protests from activists who defend rights from LGBT people (Lesbian, Gay, Bisexual, and Transgender). They demand that their rights be recognized by the state, the right to citizenship and demand for social equality in society. On the other hand, from religious leaders or organizations based on religion they strongly reject this LGBT practice in Indonesia. Both have arguments and reasons for each in their defense activities. But in this case the government has not determined a firm attitude towards LGBT actors in Indonesia. This also raises a polemic in law enforcement circles, where LGBT activities are basically very contrary to the norms that exist in Indonesia and do not reflect the civilized Indonesian culture. The law enforcers can only target LGBT people who have sex parties or engage in same-sex sex together. Law enforcement officers use Law No. 44 of 2008 concerning Pornography in disciplining LGBT actors, especially Homosexuals (gay).
\end{abstract}

Keywords: Relationships of a kind; Gay; Law Enforcement; Law No.44 of 2008 concering Pornography.

\begin{abstract}
Abstrak
Hubungan semacam itu sudah lama ada di Indonesia, tetapi akhir-akhir ini tahun ini ada berbagai macam polemik. Pro dan kontra dari penyertaan dan penyedap dalam kasus-kasus yang semakin membuat kasus ini bersemangat dan viral di masyarakat. Ini muncul dari gejolak protes dari aktivis yang membela hak-hak orang LGBT (Lesbian, Gay, Biseksual, dan Transgender). Mereka menuntut agar hak-hak mereka diakui oleh negara, hak kewarganegaraan, dan tuntutan kesetaraan sosial dalam masyarakat. Di sisi lain, dari para pemimpin agama atau organisasi berbasis agama mereka sangat menolak praktik LGBT ini di Indonesia. Keduanya memiliki argumen dan alasan untuk masingmasing dalam kegiatan pertahanan mereka. Namun dalam hal ini pemerintah belum menentukan sikap tegas terhadap pelaku LGBT di Indonesia. Ini juga menimbulkan polemik di kalangan penegak hukum, di mana kegiatan LGBT pada dasarnya sangat bertentangan dengan norma-norma yang ada di Indonesia dan tidak mencerminkan budaya Indonesia yang beradab. Para penegak hukum hanya dapat menargetkan orang LGBT yang melakukan pesta seks atau melakukan seks sesama jenis bersama. Petugas penegak hukum menggunakan UU No. 44 tahun 2008 tentang Pornografi dalam mendisiplinkan aktor LGBT, terutama Homoseksual (gay).
\end{abstract}

Kata Kunci: Hubungan sejenis; Gay, Penegakan Hukum; konkurensi UU No.44 tahun 2008 Pornografi.

\section{Pendahuluan}

Gay adalah sebuah istilah yang umumnya digunakan untuk merujuk orang homoseksual atau sifat-sifat homoseksual. Istilah ini awalnya digunakan 
untuk mengungkapkan perasaan "bebas/ tidak terikat", "bahagia" atau "cerah dan menyolok". Kata ini mulai digunakan untuk menyebut homoseksualitas mungkin semenjak akhir abad ke-19 M, tetapi menjadi lebih umum pada abad ke-20. Dalam bahasa Inggris modern, gay digunakan sebagai kata sifat dan kata benda, merujuk pada orang 'terutama pria gay' dan aktivitasnya, serta budaya yang diasosiasikan dengan homoseksualitas.

Pada akhir abadke-20, istilah "gay" telah direkomendasikan olehkelompok-kelompok besar LGBT dan paduan gaya penulisan untuk menggambarkan orang-orang yang tertarik dengan orang lain yang berkelamin sama dengannya. Pada waktu yang hampir bersamaan, penggunaan menurut istilah barunya dan penggunaannya secara peyoratif menjadi umum pada beberapa bagian dunia. Di Anglosfer, konotasi ini digunakan kaum muda untuk menyebut "sampah" atau "bodoh" (misalnya pada kalimat: "Hal tersebut sangat gay"). Dalam konteks ini, kata gay tidak memiliki arti "homoseksual" sehingga bisa digunakan untuk merujuk benda tak bergerak atau konsepsi abstrak yang tidak disukai. Dalam konteks yang sama, kata "gay" juga digunakan untuk merujuk kelemahan atau ketidakjantanan. Namun, saat digunakan dalam konteks ini, apakah istilah gay masih memiliki konotasi terhadap homoseksualitas, masih diperdebatkan dan dikritik dengan kasar.

Menurut Kartini-Kartono dalam bukunya yang berjudul "Patologi Sosial". Jilid 1 Edisi baru, pelacuran didefinisikan sebagai berikut :

1. Prostitusi adalah bentuk penyimpangan seksual, dengan pola-pola organisasi impuls/dorongan seks yang tidak wajar dan tidak terintegrasi, dalam bentuk pelampiasan nafsu-nafsu seks tanpa kendali dengan banyak orang (promiskuitas), disertai eksploitasi dan komersialisasi seks yang tanpa afeksi sifatnya.

2. Pelacuran merupakan peristiwa penjualan diri (persundalan) dengan jalan memperjualkan badan. Kehormatan dan kepribadian kepada banyak orang untuk memuaskan nafsu-nafsu seks, dengan imbalan pembayaran.

3. Pelacuran ialah perbuatan perempuan atau laki-laki yang menyatakan badanya untuk berbuat cabul sevara seksual dengan mendapatkan upah. ${ }^{1}$

\footnotetext{
1 Kartini Kartono, Patologi Sosial, Jilid 1 (Edisi Baru 2001).[207].
} 
Kegiatan melacurkan diri ini dilakukan baik sebagai kegiatan sambilan atau pengisi waktu senggang, maupun sebagai pekerjaan penuh atau profesi. Pelacur wanita disebut dalam bahasa asingnya prostitute, sedang istilah kasarnya adalah sundal, balon, lonte atau Pekerja Seks Komersial (Pekerja Seks Komersial). Maka pada tahun 60-an oleh beberapa pihak terutama dari Dinas Sosial, untuk memperluas digunakan istilah wanita tuna susila, sedang pelacur pria disebut gigolo. ${ }^{2}$

Dalam operasinya dunia pelacuran memiliki berbagai cara . Donald E. J. Mac Namara dalam bukunya yang berjudul "Sec, Crime, and The Law", menulis adanya stratifikasi dalam dunia prostitusi, yaitu antara lain sebagai berikut :

1. Street Walker adalah pelacur-pelacur yang beroperasi di jalanan. Jenis pelacur ini adalah yang paling rendah. Mereka lazimnya beroperasi pada malam hari sehingga disebut pula sebagai ladies of the night.

2. Bad Girl yaitu wanita-wanita yang bekerja di bar sebagai pelacur. Kemudian wanita-wanita yang mencari mangsa di hotel-hotel. Ada pula yang disebut store prostitute, yaitu wanita yang bekerja sebagai tukang pijat sekaligus praktek prostitusi.

3. The Legend Prostitute, yaitu pelanggan mereka adalah golongan kelas atas dengan bayaran yang amat tinggi. Dengan demikian kencan mereka hanya dengan orang pilihan. ${ }^{3}$

Kelompok lesbian, gay, biseksual, dan transgender (LGBT) di Indonesia menghadapi tantangan hukum dan prasangka yang tidak dialami oleh warga non-LGBT. Adat istiadat tradisional kurang menyetujui homoseksualitas dan berlintas-busana, yang berdampak pada kebijakan publik. Misalnya, pasangan sesama jenis di Indonesia, atau rumah tangga yang dikepalai oleh pasangan sesama jenis, dianggap tidak memenuhi syarat untuk mendapatkan perlindungan hukum yang lazim diberikan kepada pasangan lawan jenis yang menikah. Sebagian besar wilayah Indonesia tidak memiliki hukum sodomi dan saat ini tidak mengkriminalisasi perilaku homoseksual pribadi dan non-

\footnotetext{
2 ibid.[208].

3 Made Darma Weda, Kriminologi Manajement (PT Raja Grafindo 1996).[100].
} 
komersial di kalangan orang dewasa, namun hukum di Indonesia tidak melindungi komunitas LGBT terhadap diskriminasi dan kejahatan kebencian. Di Aceh, dan bagi umat Islam di kota Palembang, homoseksualitas adalah ilegal di bawah hukum Syariah Islam, dan diancam dengan hukuman cambuk. Saat ini, Indonesia tidak mengakui pernikahan sesama jenis. Pada Juli 2015, Menteri Agama Lukman Hakim Saifuddin menyatakan bahwa hal itu tidak dapat diterima di Indonesia, karena norma-norma agama berbicara keras menentang hal tersebut. Pentingnya harmoni sosial di Indonesia menyebabkan penekanan kepada kewajiban daripada hak, yang berarti bahwa hak asasi manusia bersama dengan hak-hak LGBT tergolong sangat rapuh. Namun, komunitas LGBT di Indonesia perlahan-lahan menjadi terus lebih terlihat dan aktif secara politik.

Melela ke keluarga dan teman-teman jarang dilakukan oleh orang-orang LGBT di Indonesia, karena mereka takut akan penolakan dan reaksi sosial. Namun demikian, ada beberapa contoh langka dari keluarga yang memahami dan menerima anggota keluarga dari orang LGBT. Pada tahun 1982, kelompok hak asasi gay didirikan di Indonesia. Lambda Indonesia dan organisasi sejenis lainnya bermunculan pada akhir tahun 1980-an dan 1990-an.Kini, asosiasi LGBT utama di Indonesia adalah "Gaya Nusantara”, “Arus Pelangi”, Ardhanary Institute, GWL INA.

\section{Pergerakan gay dan lesbian di Indonesia adalah salah satu yang tertua dan terbesar di Asia Tenggara.}

Kegiatan Lambda Indonesia termasuk mengorganisir pertemuan sosial, peningkatan kesadaran dan menciptakan buletin, tetapi kelompok ini dibubarkan pada tahun 1990-an. Gaya Nusantara adalah sebuah kelompok hak asasi gay yang berfokus pada isu-isu homoseksual seperti AIDS. Kelompok lain adalah Yayasan Srikandi Sejati, yang didirikan pada tahun 1998, fokus utama mereka adalah masalah kesehatan yang berkaitan dengan orang-orang transgender dan pekerjaan mereka termasuk memberikan konseling HIV/AIDS dan kondom gratis untuk transgender pekerja seks di sebuah klinik kesehatan gratis. Sekarang ada lebih dari tiga puluh kelompok LGBT di Indonesia. 


\section{Metode Penelitian}

\section{Tipe Penelitian}

Tipe penelitian dalam penyusunan jurnal ini menggunakan yuridis normatif. Yang artinya substansi pada jurnal ini lebih ditekankan pada pengkajian menurut peraturan perundang undangan ataupun peraturan peraturan lainya yang ada di pasal 7 Undangundang No. 12 tahun 2011 tentang pembentukan peraturan perundang- undangan.

\section{Pendekatan Masalah}

Penulisan jurnal ini menggunakan tiga pendekatan masalah yaitu menggunakan peraturan perundang-undangan (statute approach). Pendekatan kasus (case approach) dan pendekatan konseptual (conceptual approach). Pendekatan perundang-undangan (statute approach) adalah metode pendekatan masalah dengan menelaah semua undang-undang dan regulasi yang bersangkut paut dengan isu hukum. ${ }^{4}$ Pendekatan ini dilakukan dengan menganalisa peraturan perundangundangan yang terkait dengan penegakan hukum bagi Pekerja Seks Komersial dan kejahatan terkait dengan prostitusi. Pendekatan kasus (case approach) adalah metode pendekatan masalah melakukan telaah terhadap kasus-kasus yang berkaitan dengan isu tentang penangkapan pelaku hubungan sejenis khususnya gay.5 Pendekatan ini digunakan untuk mengetahui implementasi dari legislasi dan regulasi yang mengatur tentang penangkapan gay. Pendekatan konseptual (conceptual approach) adalah metode pendekatan masalah yang beranjak dari pandangan-pandangan dan doktrindoktrin yang berkembang dalam ilmu hukum. ${ }^{6}$ Pendekatan ini digunakan untuk menguji terkait sanksi pidana terhadap pekerja seks komersia dalam penerapanya.

\section{Aturan yang Mengatur Tentang Homoseksualitas (Gay)}

Memang aturan yang mengatur secara spesifik mengenai kegiatan homoseksualitas khsusnya gay belum ada di Indonesia. Namun beberapa Undang-

\footnotetext{
4 Peter Mahmud Marzuki, Penelitian Hukum,(Kencana, 2010) [136]

5 ibid.[158].

6 ibid.[177].
} 
undang terkait dengan pencabulan dan perkawinan secara tidak langsung dapat bula berlaku. Yakni pada Undang-undang No 1 Tahun 1974 tentang Perkawinan, tepatnya pada pasal satu dijelaskan bahwa "Perkawinan adalah ikatan lahir batin antara seorang pria dan seorang wanita sebagai suami istri dengan tujuan membentuk keluarga atau rumah tangga yang bahagia dan kekal berdasarkan Ketuhanan Yang Maha Esa".

Kata melawan hukum adalah kata yang sudah baku digunakan untuk menterjemahkan kata dari bahasa Belanda onrechtmatige atau wederrechtelijk atau dari bahasa inggris unlawful. Dengan demikian onrechtmatige atau wederrechtelijk atau unlawfulness dapat diterjemahkan sifat melawan hukum atau bersifat melawan hukum. Terminologi wederrechtelijk lebih sering digunakan dalam bidang hukum pidana, sedangkan onrechtmatige dalam bidang hukum perdata. Sehingga tindak pidana (strafbaar feit) dalam hukum pidana pada intinya adalah feit yang wederrechtelijk atau perbuatan yang melawan hukum.

Yang disebut melawan hukum formil ialah dimana dia melanggar apa yang ada di dalam undang-undang. Dari sudut normatif, setiap perbuatan yang dilarang Undang-undang mengandung sifat melawan hukum. Pandangan formil juga dianut dalam praktik hukum, seperti yang tercermin dalam pertimbangan hukum putusan Mahkamah Agung No. 30 K/Kr./1069 tanggal 6 Juni 1970, yang menyatakan bahwa “dalam setiap tindak pidana selalu ada unsur sifat melawan hukum dari perbuatan yang dituduhkan, walaupun dalam rumusan delik tidak selalu dicantumkan". ${ }^{7}$

Berdasarkan isi pasal di atas sudah jelaslah bahwa pernikahan yang dilakukan oleh sesama jenis dilarang oleh undang-undang pernikahan. Karena dalam pasal ini pernikahan hanya dapat dilakukan oleh seorang pria dan seorang wanita saja. Bukan seorang pria dengan seorang pria atau pun sebaliknya seorang wanita dengan seorang wanita. Oleh karena itu pernikahan sesama jenis tidak dapat dilakukan di Negara Indonesia selama undang-undang No1 tahun 1974 ini belum diubah.

7 A. Soema Dipradja, 1977. Himpunan Putusan Mahkamah Agung Disertai Kaedah-kaedahnya (Penerbit Akumni).[336]. 
Sebaliknya ada yang berpendapat bahwa belum tentu kalau semua perbuatan yang mencocoki larangan undang-undang bersifat melawan hukum. Bagi mereka ini uang dinamakan hukum bukanlah undang-undang saja, di samping undangundang (hukum yang tertulis) ada pula hukum yang tidak tertulis, yaitu normanorma atau kenyataan-kenyataan yang berlaku dalam masyarakat. Pendirian yang demikian dinamakan pendirian yang material. Seorang penulis (Vos) yang menganut pendirian yang material, memformulasikan perbuatan yang bersifat melawan hukum sebagai : perbuatan yang oleh masyarakat tidak diperbolehkan. Seseorang dapat dikenai sanksi pidana di dalam suatu undang-undang apabila mencocoki isi pasal dan dipandang sebagai suatu delik terhadap apa yang dilakukanya sebagai perwujudan perlawanan terhadap undang-undang. ${ }^{8}$

Seperti dalam kasus prostitusi online yang dilakukan oleh artis ataupun bukan artis. Terdapat peraturan perundang undangan yang mengatur tentang tindakan yang bertentangan dengan konten-konten yang ada di media elektronik yang mengandung unsur asusila atau pornografi. Dimana terdapat pada pasal 27 ayat (1) undangundang No. 11 tahun 2008 tentang Informasi Transaksi Elektronik. Bunyi Pasal 27 ayat (1) ialah setiap orang dengan sengaja dan tanpa hak mendistribusikan dan/ atau mentransmisikan dan/atau membuat dapat diaksesnya Informasi Elektronik dan/atau Dokumen Elektronik yang memiliki muatan yang melanggar kesusilaan. Dimana mucikari atau pekerja seks komersial tunggal (tanpa mucikari) yang dengan sengaja dan tanpa hak mendistribusikan dan atau membuat dapat diaksesnya informasi elektronik dan atau dokumen elektronik yang memiliki muatan yang melanggar kesusilaan. Yakni mucikari atau pekerja seks komersial tunggal (tanpa mucikari) yang mempublikasikan iklan tentang prostitusi di media online seperti twitter, facebook, ataupun bbm dan lain sebagainya.

Biasanya di dalam memasarkan jasa seks nya , mucikari atau pelacur bukan dari kalangan artis memakai foto palsu atau memberikan identitas palsu di dalam profil media sosialnya, tetapi mencantumkan kontak berupa no handphone yang 
benar yang bertujuan untuk mengamankan identitasnya demi kelancaran bisnis prostitusi mereka agar sulit terlacak oleh pihak kepolisian. Dan ada juga yang memakai foto asli namun tidak memperlihatkan bagian wajah, tetapi bagian intim yang diperlihatkan demi menarik peminat pria hidung belang.

Berbeda halnya dengan pekerja seks komersial dari kalangan artis, mereka tidak menyamarkan identitas karena identitas mereka dari kalangan para artis tentunya sudah diketahui banyak orang karena sudah tampil di berbagai acara di televisi. Disamping sudah terkenal, pekerja seks komersial dari kalangan artis ini memiliki fisik yang bagus dan dapat menggoda para pria hidung belang. Hal itu lah yang membuat prostitusi artis menjadi mahal harganya. Tak tanggung tanggung mucikari dari para pekerja seks komersial artis tersebut mematok harga puluhan juta rupiah. Contohnya saja artis Amel Alvi dipatok dengan harga 80 juta rupiah, tak heran pelangganya hanya dari golongan kelas atas saja yang memakai jasanya. Staf Ahli Menteri Kominfo Bidang Komunikasi dan Media Massa Hendri Subiakto mengatakan pegiat prostitusi online akan dijerat pasal 27 ayat 1. Isi pasal itu, "setiap Orang dengan sengaja dan tanpa hak mendistribusikan dan/atau mentransmisikan dan/atau membuat dapat diaksesnya Informasi Elektronik dan/atau Dokumen Elektronik yang memiliki muatan yang melanggar kesusilaan.”

"Ini bisa dijerat dengan UU ITE. Jangan main-main. Dikira nggak melanggar hukum itu. Terlebih ada foto-foto mesum di sana," kata Hendri saat berbincang dengan suara.com. ${ }^{9}$

Selain pasal 1 Undang-undang No.1 tahun 1974 pasal 2 ayat 1 undang-undang yang sama juga menjelaskan bahwa "Perkawinan adalah sah apabila dilakukan menurut hukum masing-masing agama dan kepercayaannya itu." Dalam islam perbuatan LGBT merupakan perbuatan yang keji dan melampaui batas sehingga dilaknat oleh Allah SWT.

Pada Undang-undang No.1 tahun 1974 tidak ada aturan pidana yang mengatur perbuatan LGBT. Sehingga seandainya terjadi pernikahan tersebut, pernikahan

\footnotetext{
${ }^{9}$ www.kominfo.go.id, Pegiat Prostitusi Online Bisa Dijerat UU ITE, diakses tanggal 17 September 2016
} 
itu hanya dianggap tidak pernah ada dan tidak ada sanksi pidana apapun yang diberikan kepada pelaku pernikahan LGBT.

Namun pada tahun 2002, pemerintah Indonesia memberi Aceh hak untuk memberlakukan hukum Syariah pada tingkat daerah/provinsi. Maka berdasarkan hukum syariah, homoseksualitas dianggap sebagai suatu kejahatan atau tindakan kriminal. Walaupun pada awalnya hukum syariah hanya berlaku bagi orang Muslim, pada perkembangannya juga berlaku kepada semua pihak di Aceh. Kota Palembang juga ikut menerapkan hukuman penjara dan denda terhadap tindakan hubungan seksual homoseksual. Di bawah hukum syariah, homoseksualitas didefinisikan sebagai tindakan 'prostitusi yang melanggar normanorma kesusilaan umum, agama, dan norma hukum dan aturan sosial yang berlaku' Berikut tindakannya didefinisikan sebagai tindakan prostitusi: seks homoseksual, lesbian, sodomi, pelecehan seksual, dan tindakan pornografi lainnya. Sejak saat itu, sebanyak lima puluh dua daerah ikut memberlakukan hukum berbasis syariah dari Alquran, yang mengkriminalisasikan homoseksualitas.

Enam tahun terakhir, terutama sejak Indonesia dilanda krisis multidimensional pada tahun 1997, prostitusi di kalangan anak-anak dan remaja menunjukan angka yang meningkat. Sejak krismon 1998 melanda, setiap tahunya sekitar 150 ribu wanita menjadi pelacur. Kenapa angka pelacuran menjadi sebanyak ini, faktornya adalah menyangkut masalah sosial, ekonomi, pendidikan angka putus sekolah, kesehatan, terutama yang menyangkut ketergantungan kepada narkotika oleh lingkungan di sekelilingnya. Gara-gara lemahnya penanganan pemerintah terhadap masalah prostitusi, perdagangan perempuan, Indonesia masuk kategori Negara tertinggi nomor ketiga sedunia setelah Rusia dan Thailand. Akibat ini pula, tanggal 12 juli 2001 pemerintah Indonesia mendapat kiriman surat dari Pemerintah AS. Surat tersebut berisi pernyataan pemerintah AS bahwa Indonesia adalah Negara yang sangat tidak memperdulikan persoalan perdagangan perempuan. ${ }^{10}$

\footnotetext{
${ }^{10}$ Media Aktual Wanita Masa Kini, Metropolitan, No. 24 Tahun ke III, Maret 2003.
} 
Di Jakarta, lesbian, gay, biseksual dan transgender secara hukum diberi label sebagai "Cacat" atau cacat mental dan karenanya tidak dilindungi oleh hukum. Sementara Indonesia telah memungkinkan hubungan seksual pribadi dan konsensus antara orang-orang dari jenis kelamin yang sama sejak tahun 1993, memiliki usia yang lebih tinggi dari persetujuan untuk hubungan sesama jenis dari hubungan heteroseksual (17 untuk heteroseksual dan 18 untuk homoseksual).

Konstitusi tidak secara eksplisit membahas orientasi seksual atau identitas gender. Itu menjamin semua warga dalam berbagai hak hukum, termasuk persamaan di depan hukum, kesempatan yang sama, perlakuan yang manusiawi di tempat kerja, kebebasan beragama, kebebasan berpendapat, berkumpul secara damai, dan berserikat. Hak tersebut semua jelas dibatasi oleh undang-undang yang dirancang untuk melindungi ketertiban umum dan moralitas agama.

\section{Penggunaan Undang-undang No. 44 Tentang Pornografi Dalam Penangkapan Pelaku Gay}

Dilansir dari sebuah laman berita online, lima laki-laki yang diduga tengah melakukan pesta di sebuah vila di daerah Cipanas ditangkap polisi di Cianjur pada hari Sabtu tanggal 13 Januari lalu. Dilansir Antara, salah satu dari kelima lakilaki tersebut merupakan remaja usia 16 tahun. Laki-laki berinisial AAW (50) yang tertangkap saat itu kemudian ditetapkan sebagai tersangka. AAW disebut sebagai pihak yang menentukan lokasi, memfasilitasi, dan menjadi penghubung pertama orang-orang yang terlibat dalam kegiatan di vila tersebut. Empat laki-laki lainnya ditetapkan sebagai saksi.

Yang turut serta melakukan, yaitu seorang pembuat turut serta mengambil prakarsa dengan berunding dengan orang lain dan sesuai dengan perundingan itu mereka bersama-sama melaksanakan delik. ${ }^{11}$

Pada Minggu 14 Januari 2018 Kapolres Cianjur, AKBP Soliyah sempat mengungkapkan kepada Antara, para laki-laki yang ditangkap sehari sebelumnya

\footnotetext{
11 Frans Maramis, Op.Cit, [217].
} 
akan dikenakan pasal 36 UU No. 44 Tahun 2008 tentang Pornografi. Dalam pasal tersebut disebutkan, "Setiap orang yang mempertontonkan diri atau orang lain dalam pertunjukan atau di muka umum yang menggambarkan ketelanjangan, eksploitasi seksual, persenggamaan, atau yang bermuatan pornografi lainnya sebagaimana dimaksud dalam Pasal 10 dipidana dengan pidana penjara paling lama 10 (sepuluh) tahun dan/atau pidana denda paling banyak Rp5.000.000.000,00 (lima miliar rupiah)".

Pada Mei 2017, undang-undang ini juga dipakai untuk menjerat sejumlah lakilaki yang terlibat dalam pesta gay The Wild One yang diadakan di daerah Kelapa Gading. Sebelumnya, di sebuah kamar hotel di Surabaya, polisi juga melakukan penggerebekan. Sebanyak 14 orang ditangkap dalam penggerebekan tersebut. Mereka dituding melanggar pasal 32, 33, dan 34 UU Pornografi dan pasal 45 UU ITE.

Dalam tindak pidana Pasal 30 jo Pasal 4 Ayat (2) yang harus selesai ialah perbuatan menyediakan jasa pornografi. Tidak penting apakah sudah ada atau belum orang yang menggunakan jasa pornografi tersebut. Adanya orang yang sudah menggunakan jasa pornografi yang ditawarkan si pembuat, sekedar sebagai keadaan yang memperkuat pembuktian bahwa si pembuat benar telah menyediakan jasa pornografi. Bukan merupakan syarat penyelesaian tindak pidana. Syarat penyelesaian tindak pidana sepenuhnya pada selesainya menyediakan jasa pelayanan seksual dengan menawarkan (langsung) atau mengiklankan (tidak langsung). Jika sudah ditawarkan atau sudah di iklankan, maka selesailah tindak pidana Pasal 30 jo Pasal 4 ayat (2) Undang-undang No. 44 tahun 2008 Tentang Pornografi. ${ }^{12}$

Penggunaan pasal-pasal yang ada di dalam undang-ndang no.44 tahun 2008 tentang pornografi terhadap penangkapan pelaku hubungan homoseksual khususnya gay ini tampaknya menjadi suatu dinamika hokum tersendiri. Manakala di dalam isi pasal secara literaly masih banyak dikategorikan belum mencocoki isi dari rumusan pasal tetapi sudah digunakan untuk menjerat suatu tindakan yang semestinya menggunakan pasal lain di undang-undang lain pula yang lebih mencocoki.

${ }^{12}$ Adami Chazawi, Op.Cit.[184-185]. 
Misalnya, pada kasus tertangkapnya pelaku homoseksual di vila daerah Cipanas pelakunya ada yang berusia 16 tahun, dalam hal ini seharusnya apparat kepolisian menggunakan pasal 292 KUHP. Hal ini dilakukan karena pelaku masih di bawah umur dan masuk ke dalam kategori perbuatan cabul.

\section{Kebijakan Pemerintah}

Pemerintah harus segera mengambil tindakan untuk mengatasi permasalahan ini, yakni dengan membuat aturan yang secara khusus mengatur tentang LGBT khususnya gay. Agar tidak lagi timbul polemik di kalangan aktivis pembela hak LGBT dengan golongan penolak LGBT. Dilansir dari repubilka.co Ketua Dewan Perwakilan Rakyat Bambang Soetsatyo mengatakan DPR dan Majelis Ulama Indonesia sudah berkesepahaman terkait materi Lesbian, Gay, Biseksual dan Transgender atau LGBT dalam rancangan Kitab Undang-undang Hukum Pidana (RKUHP).’Pansus RKUHP sudah terima kajian dari MUI terkait masukannya pada revisi KUHP,” kata Bambang di kantor MUI pada Selasa, 6 Februari 2018.

Adapun pandangan MUI terkait RKUHP, yaitu menyorot pembahasan mengenai pasal perzinaan. Dalam KUHP, zina hanya untuk orang yang sudah mempunyai pasangan suami istri. MUI meminta agar perzinaan itu diberlakukan untuk semua hubungan suami istri di luar pernikahan.

Dengan kesepakatan DPR dan MUI atas materi LGBT di dalam RKUHP hal ini menjadi angina segar bagi masyarakat Indonesia. Karena masyarakat telah lama gusar dengan tingkah laku LGBT dan pendukungya. Kelakuan mereka sungguh tidak mencerminkan pribadi bangsa Indonesia yang beradab dan agamis. Banyak norma-norma yang bertentangan dengan LGBT itu sendiri yang sudah tidak dapat dibenarkan oleh akal sehat maupun ilmiah.

Telah menjadi sebuah kesulitan baru bahwa pergerakan pornografi sudah merambah ke dalam dunia maya, sementara KUHP hanya mengatur hal-hal umum yang belum bisa menjangkau ke dunia maya. Delik yang berkaitan dengan 
pornografi di atur dalam Pasal 282 KUHP, yang bunyinya sebagai berikut. ${ }^{13}$

a. Barangsiapa menyiarkan, mempertunjukan atau menempelkan, gambaran atau benda, yang diketahui isinya dan melanggar kesusilaan, atau barangsiapa dengan maksud untuk disiarkan, dipertunjukan atau ditempelkan di muka umum, membikin tulisan, gambaran atau benda tersebut, memasukan ke dalam negeri, meneruskanya, mengeluarkanya dari negeri, atau mempunyai dalam persediaan, ataupun barangsiapa secara terang-terangan atau dengan mengedarkan surat tanpa diminta, menawarkanya atau menunjukanya sebagai bisa didapat. Diancam dengan pidana penjara paling lama satu tahun enam bulan atau denda paling tinggi tiga ribu rupiah.

b. Barangsiapa menyiarkan, mempertunjukan atau menempelkan, gambaran atau benda, yang diketahui isinya dan melanggar kesusilaan, atau barangsiapa dengan maksud untuk disiarkan, dipertunjukan atau ditempelkan di muka umum, membikin tulisan, gambaran atau benda tersebut, memasukan ke dalam negeri, meneruskanya, mengeluarkanya dari negeri, atau mempunyai dalam persediaan, ataupun barangsiapa secara terang-terangan atau dengan mengedarkan surat tanpa diminta, menawarkanya atau menunjukanya sebagai bisa didapat, diancam jika ada alasan kuat baginya untuk menduga bahwa tulisan, gambaran atau benda itu melanggar kesusilaan dengan pidana penjara paling lama sembilan bulan atau denda paling banyak tiga ratus rupiah.

c. Kalau yang bersalah, melakukan kejahatan tersebut dalam ayat pertama, sebagai pencarian atau kebiasaan, dapat dijatuhi pidana penjara paling lama dua tahun delapan bulan atau denda paling banyak lima ribu rupiah.

\section{Kesimpulan}

Penggunaan pasal-pasal yang ada di dalam undang-ndang no.44 tahun 2008 tentang pornografi terhadap penangkapan pelaku hubungan homoseksual khususnya gay ini tampaknya menjadi suatu dinamika hokum tersendiri. Manakala

\footnotetext{
${ }^{13}$ Budi Suhariyanto, Op.Cit.[106].
} 
di dalam isi pasal secara literaly masih banyak dikategorikan belum mencocoki isi dari rumusan pasal tetapi sudah digunakan untuk menjerat suatu tindakan yang semestinya menggunakan pasal lain di undang-undang lain pula yang lebih mencocoki. Misalnya, pada kasus tertangkapnya pelaku homoseksual di vila daerah Cipanas pelakunya ada yang berusia 16 tahun, dalam hal ini seharusnya apparat kepolisian menggunakan pasal 292 KUHP. Hal ini dilakukan karena pelaku masih di bawah umur dan masuk ke dalam kategori perbuatan cabul.

Disini peran pemerintah sangatlah krusial bila dibilang, karena untuk menyelesaikan polemik ini haruslah segera merumuskan ke dalam undang undang tersendiri mengenai LGBT. Karena dirasa sangat lama apabila menunggu pengesahan RKUHP yang masih dalam tahap proses naskah akademik.

\section{Daftar Pustaka}

\section{Buku}

Peter Mahmud Marzuki, Penelitian Hukum ( Kencana 2010).

Donald, E. J., Dalam Made Darma Weda, Kriminologi Manajement (PT Raja Grafindo.1996).

Dipradja,Soema, Himpunan Putusan Mahkamah Agung Disertai Kaedahkaedahnya (Penerbit Alumni 1977).

Moeljatno, Asas-asas Hukum Pidana (PT Rineka Cipta 2009).

\section{Jurnal}

Kartini Kartono, Patologi Sosial, Jilid 1, (Edisi Baru, 2001).

Media Aktual Wanita Masa Kini, Metropolitan, (No. 24 Tahun ke III, Maret 2003).

Kartono,Kartini, Patologi Sosial, (Jilid 1, Edisi Baru, Jakarta 2001).

\section{Laman}

Tirto, “UU Pornografi yang Kerap Dipakai Untuk Menjerat Gay”, https://tirto.id/ uu-pornografi- yang-kerap-dipakai-untuk-menjerat-gay-cDnZ, diakses 18 Mei 2019. 
Tempo, “DPR dan MUI Sepakat LGBT Dipidana Dalam RKUHP”, https://nasional. tempo.co/read/1057953/dpr-dan-mui-sepakat-lgbt-dipidana-dalam-rkuhp diakses tanggal 18 Mei 2019.

www.kominfo.go.id, Pegiat Prostitusi Online Bisa Dijerat UU ITE, diakses tanggal 17 September 2016.

\section{Perundang-undangan}

Undang-undang No.44 tahun 2008 tentang Pornografi.

Undang-undang No. 1 tahun 1974 tentang Perkawinan.

HOW TO CITE: Tatag Eko Fitrianto, 'PenerapanUndang-Undang No. 44 Tahun 2008 tentang Pornografi terhadap Penangkapan Pelaku Hubungan Sejenis (Gay)' (2019) Vol. 2 No. 5 Jurist-Diction. 
--halaman ini sengaja dibiarkan kosong-- 